JIPFRI, Vol. 5 No. 2

Halaman: 59 - 71

November 2021
JIPFRI (Jurnal Inovasi Pendidikan Fisika dan Riset IImiah)

https://doi.org/10.30599/jipfri.v5i2.1186

\title{
Desain Pembelajaran Jarak Jauh Berbasis E-Learning pada Pelajaran Fisika SMA
}

\author{
Martini $^{1}$, Ismet ${ }^{2}$, Ketang Wiyono ${ }^{3}$ \\ ${ }^{1}$ Mahasiswa Magister Pendidikan Fisika, FKIP UNSRI \\ ${ }^{2,3}$ Dosen Magister Pendidikan Fisika, FKIP UNSRI \\ JI. Masjid AI Gazali, Bukit Lama, Kec. Ilir Barat I, Palembang, Sumatera Selatan \\ *Email: martini.firmansyah@gmail.com
}

\begin{abstract}
Abstrak
Latar belakang dari penelitian ini adalah adanya globalisasi menjadikan pendidikan sangat penting tersedia bagi seluruh masyarakat. Salah satu cara memperluas akses pendidikan secara signifikan adalah melalui pembelajaran jarak jauh (PJJ). PJJ dapat memberikan kenyamanan pada peserta didik untuk belajar secara mandiri dimana saja dan kapan saja. Penerapan PJJ telah banyak dilakukan dengan menggunakan LMS (Learning Management System). Tujuan dalam penelitian ini adalah menghasilkan desain pembelajaran jarak jauh berbasis e-learning pada materi suhu dan kalor yang valid dan praktis. Penelitian ini menggunakan penelitian mix method dengan model pengembangan ADDIE. Ada dua subjek dalam penelitian ini yaitu desain pembelajaran dalam google classroom dan peserta didik kelas XI MIPA 1 SMA Negeri 15 Palembang yang berjumlah 36 siswa. Instrument dalam penelitian ini adalah lembar validasi dan kepraktisan serta wawancara. Hasil analisa angket validasi media dan materi serta angket kepraktisan media dalam penelitian diperoleh skor rata-rata validasi media adalah 3,67 atau $91,75 \%$, skor rata-rata validasi materi yang diperoleh 3,31 atau $82,75 \%$ dan analisa angket kepraktisan mendapat 3,13 atau $78,07 \%$, hal ini menunjukkan bahwa media dan materi ini layak dan praktis digunakan.
\end{abstract}

Kata kunci: desain, pembelajaran jarak jauh, e-learning

\begin{abstract}
The background of this research is the existence of globalization which makes education very important for all people. One way to significantly expand access to education is through distance learning (PJJ). PJJ can provide comfort for students to study independently anywhere and anytime. The implementation of PJJ has been widely carried out using LMS (Learning Management System). The purpose of this research is to produce a distance learning design based on e-learning on valid and practical temperature and heat material. This research uses mix method research with ADDIE development model. There are two subjects in this study, namely learning design in google classroom and students of class XI MIPA 1 SMA Negeri 15 Palembang, totaling 36 students. Instruments in this study were validation and practicality sheets and interviews. The results of the media and material validation questionnaire analysis as well as the media practicality questionnaire in the study obtained an average media validation score of 3.67 or $91.75 \%$, the average material validation score obtained 3.31 or $82.75 \%$ and practicality questionnaire analysis got 3.13 or $78.07 \%$, this shows that these media and materials are feasible and practical to use.
\end{abstract}

Keywords: design, distance learning, e-learning

\section{PENDAHULUAN}

Sektor pendidikan berperan penting terhadap pengembangan global, ekonomi, sosial, dan budaya. Melalui peningkatan jumlah populasi penduduk yang bersekolah, ekonomi global dapat mencapai pertumbuhan GDP yang stabil (Chen, dkk., 2021), menurunkan jumlah persentase pengangguran di dunia (TRU, 2019), meningkatkan kualitas hidup masyarakat (Nyandra, dkk., 2018), dan meningkatkan kohesi sosial (Durrani, dkk., 2017). Selain itu, dengan meningkatnya kualitas pendidikan di suatu negara dapat mengurangi permasalahan terkait kemiskinan dan kesehatan. Sehingga dari fenomena ini, sebagai akibat dari adanya globalisasi, sangat penting untuk menjadikan pendidikan tersedia bagi seluruh masyarakat dan memotivasi mereka untuk ikut andil berpartisipasi dalam kegiatan ini. Salah satunya adalah melalui 
pembelajaran jarak jauh yang dapat menjadi sarana memperluas akses pendidikan secara signifikan.

Pembelajaran jarak jauh merupakan bagian dari pendidikan yang berfokus pada aspek pedagogik-andragogik, teknologi, dan desain sistem pembelajaran yang terintegrasi secara efektif untuk menyampaikan informasi kepada siswa/guru dan juga memungkinkan bagi peserta didik untuk berkomunikasi secara asinkron maupun sinkron (Al-Arimi, 2014). Dengan adanya globalisasi yang mendorong perkembangan teknologi informasi menghasilkan kontribusi terhadap revolusi metode-metode dalam kegiatan belajar mengajar. Sehingga pelaksanaan KBM di era global saat ini tidak lagi terbatas ruang dan waktu (Bušelić, 2012).

Pemeran utama dalam pendidikan jarak jauh (distance education) terdiri atas peserta didik, institusi, fasilitator, staf pendukung, dan administrator yang masing-masing memiliki tugas dan fungsi tertentu. Terpenuhinya kebutuhan terkait materi pembelajaran bagi siswa merupakan tujuan utama dari setiap program pendidikan jarak jauh yang efektif. Dan yang paling terpenting, diluar dari konteks ini, peran utama seorang peserta didik adalah untuk belajar.

Adapun manfaat utama dari pembelajaran jarak jauh dibandingkan dengan pembelajaran tatap muka adalah "kenyamanan" yang diberikan: peserta didik secara mandiri dapat menentukan waktu dan tempat untuk belajar, dimana mereka dapat belajar maupun bekerja secara simultan baik di rumah, di luar kota, atau bahkan di negara lain (Rakhman \& Alam, 2020). Di sisi lain, peralihan sistem terkait referensi belajar dan teknik mengajar, sebagaimana konsultasi secara tetap yang dilakukan siswa bersama guru memberikan keuntungan tambahan untuk mendidik secara personal (Kovbasnyuk \& Styfanyshyn, 2020). Secara keseluruhan, dapat disimpulkan bahwa pembelajaran jarak jauh menuntut peserta didik untuk memiliki motivasi belajar dan keterampilan organisir diri yang kuat sebagaimana istilah distance learning yang memiliki sinonim sebagai belajar mandiri; kemampuan siswa untuk dapat belajar secara independen.

Pembelajaran jarah jauh (PJJ) telah banyak diterapkan di beberapa perguruan tinggi (Brown, dkk., 2015). Adapun variasi model PJJ seperti google classroom, model dan beberapa LMS (Learning Management System) lainnya digunakan untuk menarik minat peserta didik dalam kegiatan belajar mengajar (Cavus, 2015). Tingkat efektivitas pembelajaran jarak jauh ini ditekankan melalui integrasi IT dalam proses pembelajaran yang juga berperan sebagai sarana komunikasi (Salehudin, 2020). Bentuk-bentuk dari implikasi teknologi dalam kegiatan pembelajaran tersebut yang sering dikenal dengan istilah $e$ learning. Dalam e-learning, konten yang disajikan adalah faktor utama dalam penentu keberhasilan proses pembelajaran melalui internet. Menurut Zhang \& Zhu (2017), elearning merupakan inovasi pembelajaran yang berbasis teknologi dan memiliki banyak dampak positif. Seperti pada penelitian yang telah dilakukan oleh Irianti \& Wijaya (2017) yang menunjukkan adanya peningkatan hasil belajar saat menggunakan media pembelajaran e-learning. Beberapa keuntungan yang diperoleh saat menggunakan e-learning dalam proses pembelajaran antara lain: akses belajar yang cepat dan fleksibel (Uppal, Ali, \& Gulliver, 2018), memberikan dukungan komunikasi dengan fleksibilitas pemilihan bahasa (Hirata, 2018), konten dan bahan ajar dapat dibuat dan diperbaharui secara mudah melalui proses digitalisasi (Guragain, 2016), kemudahan akses informasi tambahan melalui hyperlink yang disediakan (Lecon \& Hermann, 2020), platform e-learning yang bersifat open source mudah untuk digunakan untuk skala besar (Songbin, \& Fanqi, 2015), dan kemudahan berbagi bahan ajar dan kualitas resolusi yang baik (Kulkarni, Rai \& Kale, 2020).

Kualitas dari perkembangan kognitif peserta didik akan dipengaruhi oleh seberapa baiknya skema instruksi yang diterapkan dan metode ajar baru dibandingkan dengan metode-metode konvensional (Markova, T., Glazkova, \& Zaborova, 2017). Sehingga, kualifikasi dari institusi pendidikan merupakan komponen esensial dalam menghasilkan 
program pembelajaran jarak jauh yang berkualitas, mengadaptasi pembelajaran tatap muka ke dalam pembelajaran jarak jauh, dan pada tahap akhir yakni menciptakan lingkungan belajar virtual yang efektif (Markova, Glazkova, \& Zaborova, 2017).

Membangun e-learning yang efektif dari segi kemudahan penggunaan merupakan tantangan tersendiri bagi pengembangan produk pendidikan (Reynolds, Becker, \& Fleming, 2014). Tingkat keterampilan penggunaan teknologi peserta didik, penyajian bahan ajar yang relevan, dan dukungan terhadap tujuan interaksi dari pengguna dan sistem yang dibangun merupakan aspek-aspek krusial dalam sistem e-learning (Alshammari, Anane, \& Hendley, 2015). Selain itu, kualitas desain pembelajaran yang terstruktur juga akan berpengaruh terhadap ketercapaian tujuan pembelajaran virtual (Dobre, 2012)(Misut \& Pribilova, 2015). Beberapa penelitian terdahulu terkait dengan pengembangan e-learning pernah dilakukan oleh Wiyono, dkk., (2020) dari hasil penelitian tersebut diperoleh bahwa $e$ learning yang dikembangkan dapat meningkatkan keterampilan berpikir kritis peserta didik dengan n-gain sebesar 0,38. Pada produk yang dikembangkan oleh Bakri, dkk (2018), perangkat modul yang dihasilkan dapat diakses oleh peserta didik dengan atau tanpa jaringan internet. Penelitian terkait $E$ learning pada LMS Google Classroom pernah dilakukan oleh Huda, dkk., (2019) hasil dari penelitian ini adalah adanya pengaruh positif dari pemanfaatan Google Classroom dalam kegiatan blended learning terhadap pemahaman peserta didik terkait konsep matematika pada materi persamaan linear dua variabel. Hasil penelitian (Maryam, 2021). ditemukan bahwa pemanfaatan google classrom dalam mengemas aktivitas belajar mengajar yang meliputi distribusi materi, video pembelajaran dan evaluasi digital menunjukkan adanya peningkatan hasil belajar fisika mahasiswa di Universitas Bina Insan. Sehingga dapat disimpulkan, dalam menyiapkan pembelajaran jarak jauh perlu diperhatikan strategi yang digunakan terutama dalam mendesain sistem pembelajaran termasuk di dalamnya kualitas perangkat teknologi yang akan digunakan e-learning.

Penelitian ini bertujuan untuk menghasilkan produk desain pembelajaran jarak jauh berbasis e-learning pada pembelajaran fisika yang valid dan praktis. Adapun LMS (Learning Management System) yang dimanfaatkan berupa google classroom dengan komponen pengembangan meliputi aspek media dan materi.

\section{METODE}

Penelitian ini menggunakan penelitian mix method yaitu dengan menggunakan metode kuantuitatif dan kualitatif dalam penelitian ini instrument kuesioner berupa angket dianalisis dengan perhitungan menggunakan persamaan matematik (kuantitatif). Instrument berupa wawancara dianalisis secara kualitatif. Model pengembangan yang digunakan adalah ADDIE. Model pengembangan ADDIE memiliki 5 tahapan pengembangan yaitu: tahap analisis (analysis), tahap perancangan produk awal (design), tahap pengembangan produk (development), tahap implementasi produk (implementation), dan tahap evaluasi produk (evaluation) (Branch, 2009).

Ada dua subjek dalam penelitian ini yaitu subjek pada tahap pengembangan yaitu desain pembelajaran dalam google classroom dan subjek pada tahap evaluasi yaitu siswa kelas XI MIPA 1 SMA Negeri 15 Palembang yang berjumlah 36 siswa.

Desain penelitian jarak jauh yang digunakan adalah e-learning google classroom dengan materi suhu dan kalor. Instrumen yang digunakan dalam penelitian ini adalah kuesioner dan wawancara. Kuesioner yang disusun berupa lembar validasi dan praktikalitas produk.

\section{LEMBAR VALIDASI DAN KEPRAKTISAN}

Lembar validasi digunakan pada tahap pengembangan untuk mendapatkan validasi ahli terhadap desain yang dikembangkan. Lembar validasi disusun berdasarkan dua validitas yaitu validitas materi dan validitas desain media. Kepraktisan media diukur menggunakan lembar angket respon siswa tentang pembelajaran menggunakan google 
classroom. Data berupa skor yang diubah menjadi data kualitatif dengan ketentuan yang dijabarkan menurut Tabel 2 dari Direktorat Pembinaan SMA (Purwanto, 2010), dengan empat jenis konversi penilaian yaitu Sangat Baik (SB) bernilai 4, Baik (B) bernilai 3, Kurang (K) bernilai 2, dan Sangat Kurang (SK) bernilai 1. Penghitungan skor rata-rata untuk setiap aspek kriteria yang dinilai menggunakan persamaan 1 dalam Zamani, \& Nurcahyo, (2016).

$$
\bar{X}=\frac{\sum X}{n}
$$

Klasifikasi validitas dan praktisitas dengan kriteria yang dimodifikasi dari (Ngalim, 2010) berikut ini:

Tabel 1. Klasifikasi Validitas dan Praktikalitas

\begin{tabular}{ccc}
\hline No & Nilai Rerata & Aspek yang dinilai \\
\hline 1 & $86 \%-100 \%$ & Sangat Valid \\
2 & $76 \%-85 \%$ & Valid \\
3 & $60 \%-75 \%$ & Cukup Valid \\
4 & $55 \%-59 \%$ & Kurang Valid \\
5 & $\leq 54 \%$ & Tidak Valid \\
\hline
\end{tabular}

Tabel 2 dan Tabel 3 masing-masing menyajikan kisi-kisi validasi media dan validasi materi.

Tabel 2. Kisi-Kisi Validasi Media

\begin{tabular}{|c|c|c|c|}
\hline No & Aspek & Indikator & $\begin{array}{c}\text { Jumlah } \\
\text { Butir }\end{array}$ \\
\hline \multirow[t]{3}{*}{1} & Materi & $\begin{array}{l}\text { Kesesuaian media } \\
\text { dengan materi }\end{array}$ & 1 \\
\hline & & $\begin{array}{l}\text { Kesesuaian media } \\
\text { dengan tujuan }\end{array}$ & 1 \\
\hline & & $\begin{array}{l}\text { Kesesuaian materi } \\
\text { dengan kompetensi } \\
\text { dasar }\end{array}$ & 1 \\
\hline \multirow[t]{2}{*}{2} & Ilustrasi & $\begin{array}{l}\text { Penampilan media } \\
\text { menarik }\end{array}$ & 1 \\
\hline & & $\begin{array}{l}\text { Media mempermudah } \\
\text { dalam belajar }\end{array}$ & 1 \\
\hline \multirow[t]{2}{*}{3} & $\begin{array}{l}\text { Kualitas } \\
\text { dan }\end{array}$ & $\begin{array}{l}\text { Kekomunikatifan } \\
\text { bahasa }\end{array}$ & 1 \\
\hline & tampilan & $\begin{array}{l}\text { Ketepatan penggunaan } \\
\text { istilah }\end{array}$ & 1 \\
\hline 4 & $\begin{array}{l}\text { Daya } \\
\text { Tarik }\end{array}$ & $\begin{array}{l}\text { Pemberian motivasi } \\
\text { belajar }\end{array}$ & 2 \\
\hline
\end{tabular}

Tabel 3. Kisi-Kisi Validasi Materi

\begin{tabular}{lllc}
\hline No & Aspek & \multicolumn{1}{c}{ Indikator } & $\begin{array}{c}\text { Jumlah } \\
\text { Butir }\end{array}$ \\
\hline 1 & Materi & $\begin{array}{l}\text { Cakupan, struktur, } \\
\text { kejelasan dan } \\
\text { aktualisasi materi } \\
\text { Cakupan contoh soal }\end{array}$ & 4 \\
& & 2
\end{tabular}

\begin{tabular}{|c|c|c|c|}
\hline No & Aspek & Indikator & $\begin{array}{c}\text { Jumlah } \\
\text { Butir }\end{array}$ \\
\hline & & Kejelasan dan & 3 \\
\hline & & kesesuaian bahasa & \\
\hline & & Kesesuaian latihan & 3 \\
\hline & & $\begin{array}{l}\text { soal, runtut soal dengan } \\
\text { kompetensi }\end{array}$ & \\
\hline \multirow[t]{7}{*}{2} & Pem- & Kesesuaian kompetensi & 3 \\
\hline & belajaran & dasar dengan indikator & \\
\hline & & dan standar kompetensı & \\
\hline & & $\begin{array}{l}\text { Kejelasan judul, } \\
\text { petunjuk belajar dan } \\
\text { strateai belaiar }\end{array}$ & 5 \\
\hline & & Ketepatan materi & 3 \\
\hline & & Kejelasan petunjuk & 3 \\
\hline & & $\begin{array}{l}\text { soal, rumusan soal dan } \\
\text { tingkat kesukaran soal }\end{array}$ & \\
\hline
\end{tabular}

Lembar Kepraktisan media e-learning dimaksudkan untuk melihat apakah e-learning dapat dengan praktis digunakan untuk kegiatan pembelajaran. Data kepraktisan diambil dari siswa yang mengikuti pembelajaran dalam elearning. Kisi-kisi instrumen kepraktisan media dapat dilihat pada Tabel 4:

Tabel 4. Kisi-Kisi Kepraktisan Media

\begin{tabular}{lllc}
\hline No & Aspek & Indikator & $\begin{array}{c}\text { Jumlah } \\
\text { Butir }\end{array}$ \\
\hline 1 & Materi & $\begin{array}{l}\text { Kesesuaian media } \\
\text { dengan materi } \\
\text { Kesesuaian media } \\
\text { dengan tujuan } \\
\text { Kesesuaian materi } \\
\text { dengan kompetensi } \\
\text { dasar }\end{array}$ & 1 \\
2 & Ilustrasi & $\begin{array}{l}\text { Penampilan media } \\
\text { menarik }\end{array}$ & 1 \\
& & $\begin{array}{l}\text { Media mempermudah } \\
\text { dalam belajar }\end{array}$ & 1 \\
3 & $\begin{array}{l}\text { Kualitas } \\
\text { dan } \\
\text { tampilan }\end{array}$ & $\begin{array}{l}\text { Kekomunikatifan } \\
\text { bahasa } \\
\text { Ketepatan } \\
\text { penggunaan istilah }\end{array}$ & 1 \\
& & $\begin{array}{l}\text { Pemberian motivasi } \\
\text { belajar }\end{array}$ & 2 \\
\hline
\end{tabular}

\section{WAWANCARA}

Data yang diperoleh dari wawancara dianalisis secara deskriptif kualitatif dan dijadikan sebagai acuan untuk mengembangkan e-learning google classroom.

\section{HASIL DAN PEMBAHASAN}

\section{TAHAP ANALISIS KEBUTUHAN}

Tahap pertama yang peneliti lakukan adalah studi pendahuluan ke sekolah tempat penelitian 
dengan memberikan angket pada peserta didik serta melakukan wawancara dengan guru yang mengajar. Tujuan dari studi pendahuluan dan wawancara dengan guru fisika yang mengajar adalah untuk memperoleh data bagaimana pemanfaatan media e-learning dalam pembelajaran jarak jauh dan bagaimana kemandirian peserta didik dalam belajar.

\section{TAHAP DESAIN MEDIA PEMBELAJARAN}

Tujuan dari tahap ini adalah memberikan gambaran tentang isi dari media pembelajaran jarak jauh. Isi dari media pembelajaran google classroom diantaranya adalah halaman depan yang memperlihatkan tentang forum, tugas dan anggota group. Dalam forum guru dan peserta didik bisa berbalas chat secara umum, dalam menu tugas terdapat 5 menu yaitu pemberian tugas, pertanyaan, materi, penggunaan postingan yang pernah di buat sebelumnya dari kelas itu atau dari kelas lainnya serta pembuatan topik sehingga materi, pertanyaan serta tugas terstruktur sesuai dengan judul materi atau pertemuan. Dalam google classroom ada juga menu untuk guru dan peserta didik dapat bertemu secara virtual. Di bawah ini diberikan desain pembelajaran yang dikembangkan dalam google classroom seperti pada gambar $1 \mathrm{a}, 1 \mathrm{~b}$ dan $1 \mathrm{c}$.

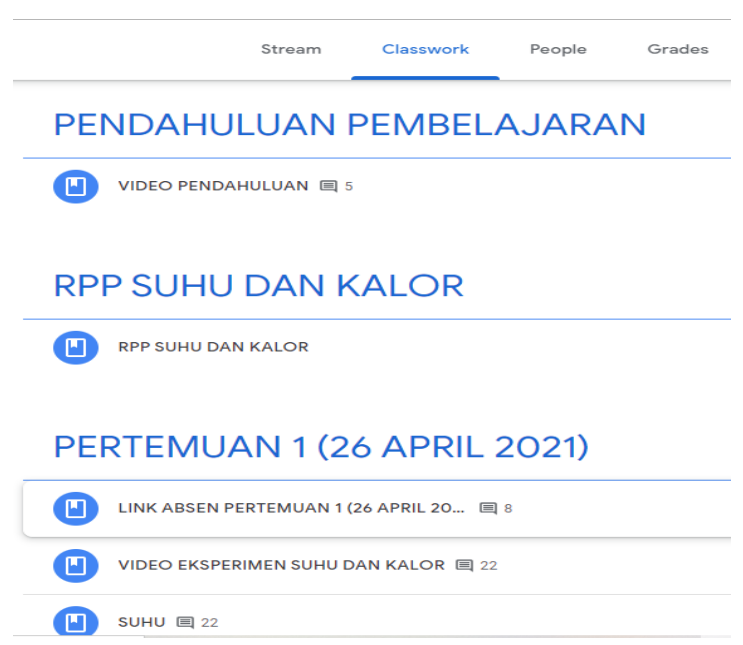

Gambar 1a. Tampilan Desain Pembelajaran

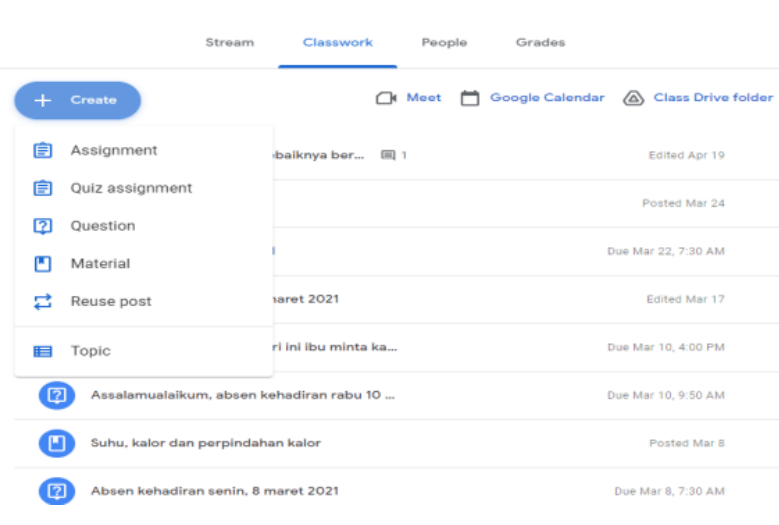

Gambar 1b. Tampilan Menu

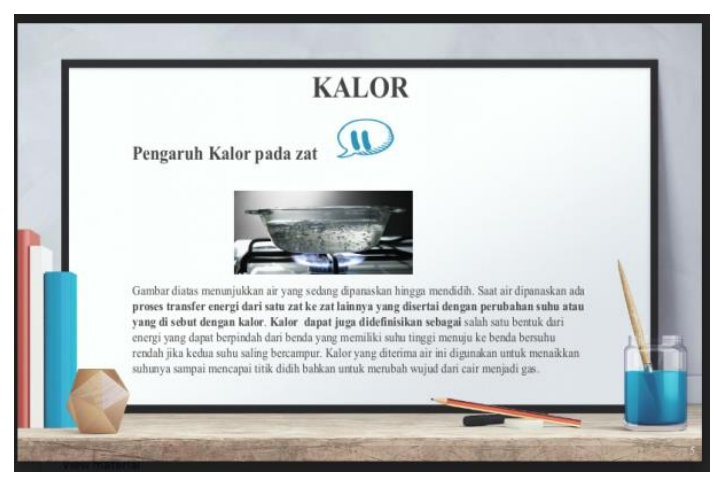

Gambar 1c. Tampilan Desain PPT

\section{TAHAP PENGEMBANGAN}

Tahap pengembangan adalah tahap pembuatan media pembelajaran jarak jauh dalam google classroom. Hasil dari tahap awal desain pembelajaran, selanjutnya dikonsultasikan dengan dosen pembimbing. Setelah media pembelajaran selesai dikonsultasikan dan menghasilkan media pembelajaran, kemudian masuk pada tahap selanjutnya yaitu validasi ahli media dan validasi ahli materi. Validasi ahli media terdiri dari satu orang dosen dan satu orang guru, validasi materi juga terdiri dari satu orang dosen dan satu orang guru yang memiliki kompetensi dalam materi fisika. Hasil dari validasi tersebut akan memperoleh kriteria kelayakan produk dan saran dari validator sehingga media pembelajaran dalam google classroom harus direvisi. Berikut ini akan ditampilkan dalam bentuk tabel 5 hasil analisis validasi media.Bagian ini memuat hasil atau data penelitian, analisis data penelitian, 
jawaban dari pertanyaaan penelitian, dan analisis terhadap temuan selama penelitian Tabel 5. Hasil Analisis Validasi Media

\begin{tabular}{|c|c|c|c|c|c|}
\hline No & Aspek yang dinilai & V1 & V2 & Jumlah & $\begin{array}{l}\text { Rata- } \\
\text { Rata }\end{array}$ \\
\hline & Materi & & & & \\
\hline 1. & Media di google classroom yang digunakan sesuai dengan materi & 4 & 4 & 8 & 4 \\
\hline 2. & pelajaran. & 4 & 4 & 8 & 4 \\
\hline 3. & $\begin{array}{l}\text { Media yang digunakan dalam google classroom sesuai dengan tujuan } \\
\text { pembelajaran. } \\
\text { Penggunaan google classroom yang digunakan sesuai dengan } \\
\text { Kompetensi Dasar. }\end{array}$ & 3 & 4 & 7 & 3,5 \\
\hline 1. & llustrasi & 3 & 3 & 6 & 3 \\
\hline 2. & $\begin{array}{l}\text { Media google classroom yang digunakan dapat memberikan ilustrasi } \\
\text { yang sesuai dengan keadaan yang sebenarnya. } \\
\text { Media google classroom dapat mempermudah siswa dalam belajar. }\end{array}$ & 4 & 3 & 7 & 3,5 \\
\hline 1. & Kualitas dan Tampilan Media & 3 & 3 & 6 & 3 \\
\hline 2. & $\begin{array}{l}\text { Penampilan media google classroom menarik perhatian siswa. } \\
\text { Media google classroom yang digunakan tidak mudah rusak. }\end{array}$ & 4 & 4 & 8 & 4 \\
\hline 1. & Daya Tarik & 4 & 4 & 8 & 4 \\
\hline \multirow[t]{2}{*}{2.} & $\begin{array}{l}\text { Penggunaan media google classroom dapat mengurangi ketergantungan } \\
\text { siswa pada guru. }\end{array}$ & 4 & 4 & 8 & 4 \\
\hline & 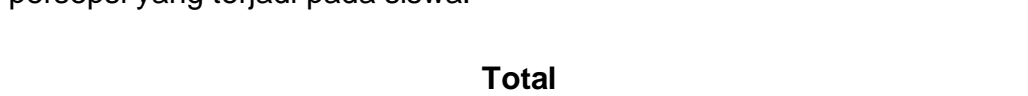 & 33 & 33 & 66 & 3,67 \\
\hline
\end{tabular}

Berdasarkan tabel 5 dapat disimpulkan bahwa media yang digunakan dinyatakan valid oleh validator media, dengan skor rata-rata yang diperoleh adalah 3,67 atau $91,75 \%$ sesuai dengan kriteria validasi yang digunakan dalam media ini apabila skor yang diperoleh adalah $86 \%-100 \%$ maka media sangat valid untuk digunakan. Selanjutnya akan dianalisis mengenai validasi materi, seperti pada tabel 6 hasil analisis validasi materi.

Tabel 6. Hasil Analisis Validasi Materi

\begin{tabular}{|c|c|c|c|c|c|}
\hline No & Aspek yang dinilai & V1 & V2 & Jumlah & $\begin{array}{l}\text { Rata- } \\
\text { rata }\end{array}$ \\
\hline & Aspek Isi/Materi & & & & \\
\hline 1. & Cakupan (keluasan dan kedalaman) isi materi & 3 & 3 & 6 & 3 \\
\hline 2. & Kesesuaian Materi dengan Karakteristik peserta didik & 3 & 3 & 6 & 3 \\
\hline 3. & Kejelasan isi materi & 3 & 3 & 6 & 3 \\
\hline 4. & Struktur organisasi/urutan isi materi & 4 & 3 & 7 & 3,5 \\
\hline 5. & Aktualisasi isi materi & 4 & 3 & 7 & 3,5 \\
\hline 6. & Kejelasan contoh yang disertakan & 4 & 3 & 7 & 3,5 \\
\hline 7. & Kecukupan contoh yang disertakan & 3 & 3 & 6 & 3 \\
\hline 8. & Kejelasan bahasa yang digunakan & 3 & 4 & 7 & 3,5 \\
\hline 9. & Kesesuaian bahasa dengan dengan sasaran pengguna & 3 & 4 & 7 & 3,5 \\
\hline 10. & Kejelasan informasi pada ilustrasi gambar & 4 & 4 & 8 & 4 \\
\hline 11. & Kesesuaian latihan/tes dengan kompetensi & 3 & 3 & 6 & 3 \\
\hline 12 & Keseimbangan proporsi soal latihan/tes dengan materi & 4 & 3 & 7 & 3,5 \\
\hline 13. & $\begin{array}{c}\text { Runtutan soal yang disajikan } \\
\text { Aspek Pembelajaran }\end{array}$ & 4 & 3 & 7 & 3,5 \\
\hline 1. & Kesesuaian kompetensi dasar dengan indikator & 3 & 3 & 6 & 3 \\
\hline 2. & Kesesuaian kompetensi dasar dengan materi program & 3 & 3 & 6 & 3 \\
\hline 3. & Kesesuaian kompetensi dasar dengan standar kompetensi & 3 & 3 & 6 & 3 \\
\hline 4. & Kejelasan judul materi & 4 & 4 & 8 & 4 \\
\hline 5. & Kejelasan sasaran pengguna & 4 & 4 & 8 & 4 \\
\hline 6. & Kejelasan petunjuk belajar (petunjuk penggunaan) & 4 & 3 & 7 & 3,5 \\
\hline
\end{tabular}




\begin{tabular}{|c|c|c|c|c|c|}
\hline No & Aspek yang dinilai & $\mathrm{V} 1$ & V2 & Jumlah & $\begin{array}{c}\text { Rata- } \\
\text { rata }\end{array}$ \\
\hline 7. & Ketepatan penerapan strategi belajar (belajar mandiri) & 3 & 3 & 6 & 3 \\
\hline 8. & Variasi penyampaian jenis informasi/data & 3 & 3 & 6 & 3 \\
\hline 9. & Ketepatan dalam penjelasan materi konseptual & 3 & 3 & 6 & 3 \\
\hline 10. & Ketepatan dalam penjelasan materi praktis & 4 & 3 & 7 & 3,5 \\
\hline 11. & Kemenarikan materi dalam memotivasi pengguna & 4 & 4 & 8 & 4 \\
\hline 12. & Kejelasan petunjuk pengerjaan soal latihan/tes & 3 & 4 & 7 & 3,5 \\
\hline 13. & Kejelasan rumusan soal/tes & 3 & 3 & 6 & 3 \\
\hline 14. & Tingkat kesulitan soal/tes & 2 & 3 & 5 & 2,5 \\
\hline & $\mathrm{u}$ & 87 & 86 & 179 & 3,31 \\
\hline
\end{tabular}

Berdasarkan tabel 6 diatas maka dapat disimpulkan bahwa materi yang digunakan dinyatakan valid oleh validator media, dengan skor rata-rata yang diperoleh adalah 3,31 atau
$82,75 \%$ sesuai dengan kriteria validasi yang digunakan dalam media ini apabila skor yang diperoleh adalah $76 \%-85 \%$ maka materi valid untuk digunakan.

Tabel 7. Hasil Analisis Kepraktisan Desain e-learning dalam Google Classroom

\begin{tabular}{llr}
\hline No & Aspek Yang Dinilai & $\overline{X_{36}}$ \\
\hline 1. & Tampilan elearning Google Classroom (GC) ini menarik & 3,00 \\
2. & Dengan menggunakan GC ini dapat membuat belajar fisika tidak bosan & 3,11 \\
3. & Adanya kata motivasi dalam GC fisika ini berpengaruh terhadap sikap dan belajar saya & 3,25 \\
4. & Dengan adanya video dapat memberikan motivasi untuk mempelajari materi & 3,60 \\
5. & Penyampaian materi dalam GC ini berkaitan dengan kehidupan sehari-hari & 2,90 \\
6. & Materi yang disajikan dalam GC ini mudah saya pahami & 3,00 \\
7. & Dalam GC ini terdapat beberapa bagian untuk saya menemukan konsep sendiri & 2,60 \\
8. & Penyajian materi dalam GC Fisika ini mendorong saya untuk belajar lebih mandiri & 3,20 \\
9. GC ini mendorong saya untuk menuliskan yang sudah saya pahami pada kolom penilaian & 2,81 \\
10 & GC memuat evaluasi yang dapat menguji pemahaman saya tentang materi suhu dan kalor & 3,22 \\
11. Kalimat yang digunakan dalam GC fisika jelas dan mudah dipahami & 3,39 \\
12. Bahasa yang digunakan dalam GC fisika ini sederhana dan mudah dimengerti & 3,47 \\
Nilai rata-rata & 3,12 \\
\hline
\end{tabular}

Selanjutnya dilakukan pemberian angket respon peserta didik untuk melihat kepraktisan dari media dan materi dalam google classroom. Angket respon peserta didik ini diberikan kepada 36 peserta didik dari tiga kelas yaitu XI MIPA 2, XI MIPA 3 dan XI MIPA 4 SMA Negeri 15 Palembang Tahun Pelajaran 2020/2021. Hasil analisis kepraktisan desain e-learning dalam google classroom dirangkum dalam Tabel 7.

Berdasarkan tabel 7 dapat disimpulkan bahwa desain pembelajaran jarak jauh berbasis e-learning dengan menggunakan google classroom dinyatakan praktis dengan skor rata-rata 3,13 atau $78,07 \%$ sesuai dengan kriteria kepraktisan yang digunakan dalam media ini apabila skor yang diperoleh adalah $76 \%$ - 85\% maka desain yang digunakan praktis untuk selanjutnya media ini dinyatakan layak untuk diujicobakan disekolah tempat peneliti melakukan penelitian. Berikut akan ditunjukkan dengan gambar tampilan media sebelum dan sesudah divalidasi.

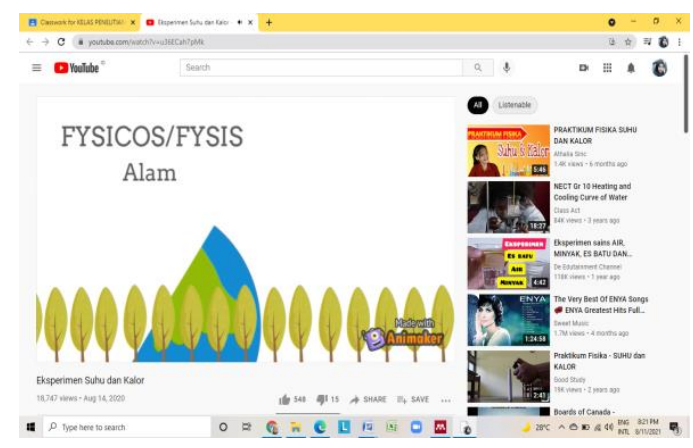

Gambar 2a. Tampilan Media Sebelum Validasi 


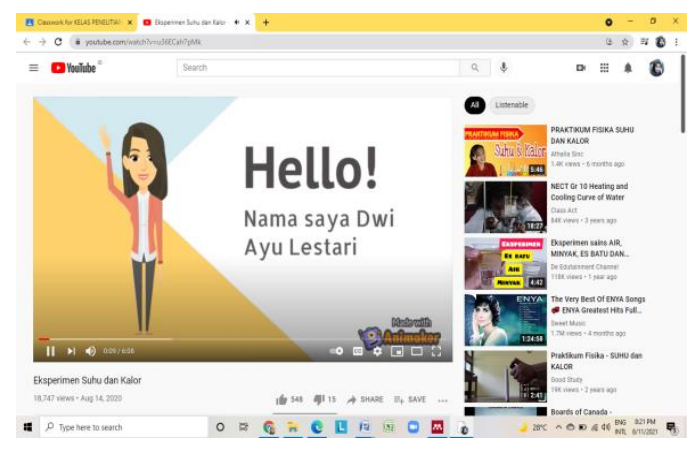

Gambar 2b. Tampilan Media Sebelum Validasi

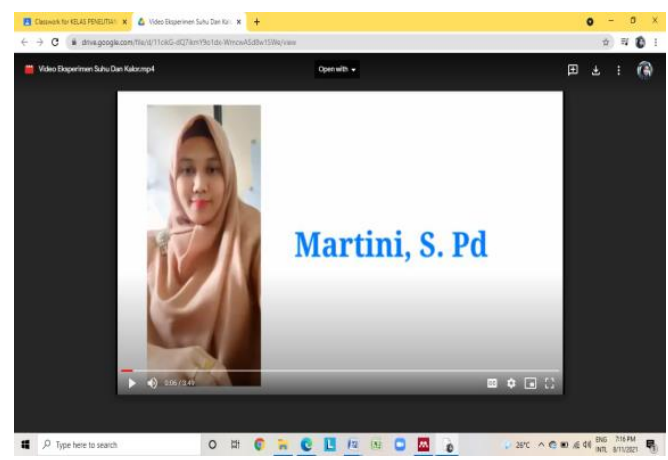

Gambar 3a. Tampilan Media Sesudah Validasi

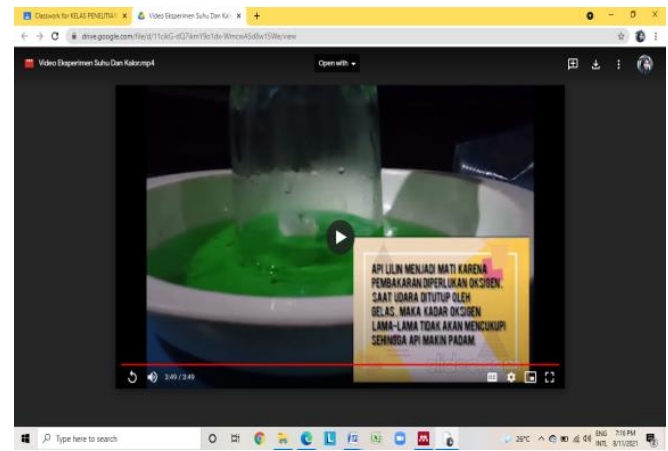

Gambar 3b. Tampilan Media Sesudah Validasi

Gambar 2 adalah tampilan video pembelajaran dalam media sebelum divalidasi menggunakan video dari youtube, sesuai saran dari validator media bahwa video pembelajaran harus dibuat sendiri oleh peneliti, tidak dengan memberikan link youtube video pembelajaran orang lain walaupun mencantumkan nama pembuatnya. Selanjutnya perbaikan pada video pembelajaran seperti pada gambar 3 , video pembelajaran dibuat sendiri oleh peneliti. Selanjutnya ditampilkan materi pada media sebelum dan sesudah divalidasi.

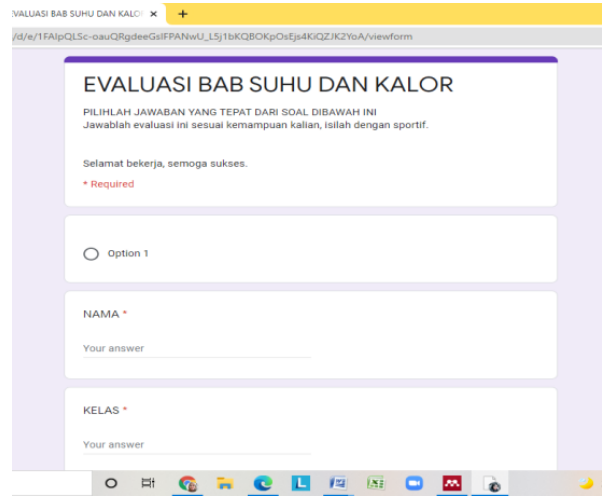

Gambar 4. Tampilan Evaluasi Sebelum Validasi

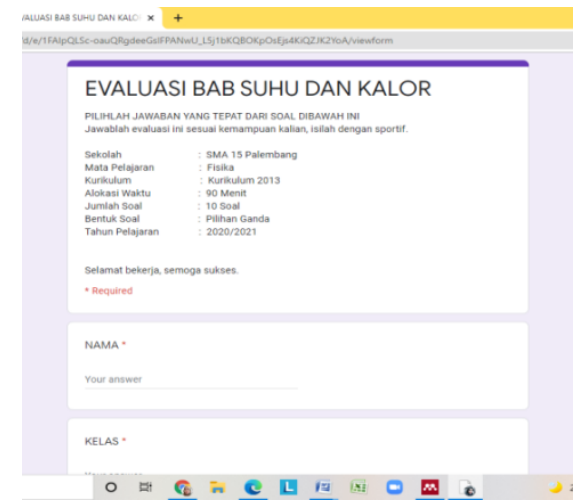

Gambar 5. Tampilan Evaluasi Sesudah Validasi

Gambar 4 adalah tampilan evaluasi akhir atau postest materi suhu kalor, sebelum divalidasi soal evaluasi belum diberi petunjuk pengerjaan soal, setelah divalidasi oleh validator materi pada gambar 5 , sudah diberi petunjuk pengerjaan soal evaluasi akhir.

\section{TAHAP IMPLEMENTASI}

Setelah dilakukan ujicoba pada tahap pengembangan, tahap selanjutnya adalah tahap implementasi atau penerapan pada sampel penelitian yaitu kelas XI MIPA 1 SMA Negeri 15 Palembang Tahun Pelajaran 2020/2021. Pada tahap penerapan ini dilihat bagaimana desain yang dikembangkan dapat lebih praktis digunakan peserta didik dalam belajar.

\section{TAHAP EVALUASI}

Hasil pengembangan media yang sudah diimplemetasikan pada sampel pelitian selanjutnya akan dievaluasi dengan menggunakan evaluasi formatif atau evaluasi akhir materi. Evaluasi akhir formatif pada materi suhu dan kalor ini dapat menganalisis 
kemandirian belajar pada konsep ini. Berdasarkan hasil wawancara yang peneliti lakukan pada beberapa peserta didik dan guru tempat peliti melakukan penelitian adalah bahwa peserta didik berharap aplikasi google classroom bisa dibuka secara offline atau tanpa menggunakan kuota, video yang disajikan bisa lebih interaktif dan bervariasi, soal yang diberikan dengan tingkat kesukaran sesuai dengan kemampuan peserta didik.

\section{PEMBAHASAN}

Ragam sistem pendidikan dan seluruh aspek didalamnya termasuk pembelajaran jarak jauh (distance learning), memiliki makna dengan perspektif yang berbeda-beda tergantung dari pengalaman pengguna. Hal ini berarti menunjukkan bahwa segi kebermanfaatan dari setiap produk pendidikan memiliki manfaat dan kerugian yang bersifat subjektif tergantung dari permasalahan yang dialami individu, nilai dan manfaat yang diperoleh melalui proses (Traxler, 2018). Sehingga dapat diperoleh bahwa pengembangan produk pendidikan dapat disesuaikan dengan keadaan lingkungan untuk mencapai tujuan yang diinginkan.

Trend pengembangan pendidikan yang terjadi di berbagai belahan dunia dikategorikan dalam tiga kelompok yaitu: jangka pendek, menengah, dan jangka panjang. Budaya inovasi dan pendalaman pengetahuan merupakan fokus utama pengembangan produk pendidikan jangka panjang. Untuk jangka pendek fokus pengembangan adalah redesain ulang pembelajaran blended dan pembelajaran kolaboratif, sedangkan untuk jangka menengah penelitian berorientasi pada asesmen dan redesain ruang pembelajaran (AlMutawa, 2017).

Desain pembelajaran jarak jauh berbasis e-learning pada penelitian ini dilakukan dengan memanfaatkan LMS google classroom. Google classroom merupakan platform yang popular dalam dunia pendidikan. Aplikasi ini menyediakan seperangkat fitur-fitur pendukung yang menjadikan LMS ini ideal dan mudah dipahami oleh peserta didik. Google classroom juga membantu guru dalam mengatur efisiensi waktu, mengorganisir kelas, dan berkomunikasi dengan siswa. Selain itu fitur-fitur yang disediakan juga memudahkan guru untuk mengelola hasil tugas peserta didik yang bersifat digital (bukan berbasis kertas) seperti melalui Google Docs, Drive, dan aplikasi lainnya (Iftakhar, 2016). Melalui layanan yang tersedia ini penulis mengembangkan desain PJJ untuk pembelajaran fisika SMA yang meliputi komponen media dan materi.

Kedua aspek ini media dan materi, selanjutnya divalidasi oleh ahli. Validitas media bertujuan untuk melihat tingkat kesahihan media pembelajaran dari segi materi, ilustrasi, kualitas dan tampilan, serta daya tarik. Sedangkan validitas materi dilakukan untuk menilai kesesuaian isi konten dari segi pedagogik.

Berdasarkan data yang ditunjukkan pada Tabel 5, dari hasil analisis validasi media ditunjukkan bahwa desain PJJ yang dikembangkan termasuk ke dalam kategori sangat baik dengan skor rerata sebesar 3,67 (skala maksimal 4). (Traxler, 2018) mengemukakan salah satu tantangan saat mendesain PJJ adalah permasalahan integrasi pembelajaran formal dan informal, lintas konteks, dan isu pemahaman dan pengalaman yang akan diperoleh oleh peserta didik. Pada desain PJJ berbasis e-learning yang dikembangkan dalam penelitian ini, daya tarik media yang digunakan memiliki aspek sangat valid untuk memberikan pengalaman mandiri kepada siswa dan meminimalisir kesalahan persepsi terhadap peserta didik. Selain itu, untuk konten ilustrasi, validator memberikan penilaian dengan kategori baik terhadap ilustrasi yang digunakan pada media. Ilustrasi yang dibuat dan disajikan merupakan ilustrasi yang sesuai dengan keadaan sebenarnya (kontekstual) sehingga media pada e-learning yang dikembangkan dapat meminimalisir permasalahan yang timbul terkait pemahaman peserta didik terhadap materi yang diberikan.

Validitas materi pada e-learning yang dikembangkan tergolong dalam kategori valid berdasarkan hasil validasi oleh kedua ahli Tabel 6. (Lister, 2014) merangkum trend penelitian terkait pengembangan online learning dan pembelajaran blended saat ini menuliskan struktur materi sebagai poin utama 
yang memerlukan perhatian khusus saat akan mendesain e-learning dan pembelajaran daring. Studi terkait (Kim et al., 2014; Lee, 2014; Swan, dkk., 2014); Teräs, \& Herrington, 2014) melaporkan bahwa penjabaran struktur materi dengan tujuan pembelajaran yang jelas, rubrik penilaian, dan contoh latihan soal, adalah komponen penting dari sebuah desain pembelajaran online. Domun, M. \& Bahadur, (2014), Kim, dkk. (2014), dan Swan, dkk., (2014) juga menambahkan penilaian mandiri terhadap konten materi yang diberikan berperan penting sebagai umpan balik kepada peserta didik. Dalam produk pengembangan desain PJJ berbasis e-learning untuk pembelajaran fisika dalam artikel ini, validasi materi meliputi aspek isi dan aspek pembelajaran. Sebagai upaya untuk menghasilkan e-learning yang terstruktur dan terorganisir, dalam lembar validasi dimasukkan aspek cakupan (keluasan dan kedalaman) isi materi dan urutan isi materi yang masingmasing terkategori baik menurut kedua validator. Kemudian dari segi pembelajaran, materi-materi yang disusun telah sesuai dengan kompetensi dasar, indikator, standar kompetensi, dan judul materi. Kemudian, terkait konten asesmen pada produk pembelajaran, sistematika penilaian telah memenuhi komponen penting e-learning pada bagian evaluasi yakni contoh soal yang jelas, petunjuk pengerjaan latihan soal/tes, rumusan soal yang jelas, dan penyampaian jenis informasi yang semuanya dalam kategori baik diharapkan akan memberikan kontribusi yang positif terhadap keterampilan peserta didik dalam belajar mandiri.

Kemudian dari segi kepraktisan desain elearning menurut perspektif pengguna peserta didik, e-learning yang dikembangkan memiliki kategori praktis. Berdasarkan data yang ditampilkan pada Tabel 7 menunjukkan bahwa mayoritas siswa setuju dengan adanya video pembelajaran yang disajikan memotivasi mereka untuk mempelajari materi. Kemudian dari produk pengembangan yang diujikan, kebanyakan siswa setuju bahwa struktur kalimat dan tata bahasa yang digunakan dalam media jelas dan mudah dipahami. Hal ini sangat esensial karena secara mendasar basis komunikasi dalam e-learning bersifat virtual, dan penyampaian kalimat yang jelas dan tertata adalah kunci untuk menghindarkan salah perspepsi atau ketidaktercapaian tujuan pembelajaran kepada peserta didik. Akan tetapi, beberapa siswa menyatakan bahwa mereka kesulitan untuk menemukan konsep secara mandiri. Mereka juga tidak percaya diri untuk menuliskan rangkuman materi dari materi yang telah mereka pahami di kolom penilaian diri. Kedua hal ini yang kemudian perlu untuk diperhatikan dan diteliti lebih lanjut secara spesifik untuk mengetahui penyebabnya. Popa \& Stănculea, (2012) menyebutkan istilah elearning memiliki arti untuk semua tipe pembelajaran termasuk belajar mandiri yang bertujuan untuk memperoleh pengetahuan oleh peserta didik baik melalui pengalaman individu maupun keterampilan teknis. Oleh karena itu, e-learning yang dikembangkan sebaiknya juga bersifat seperti tujuan belajar pada kelas tatap muka pada umumnya, yakni mendapatkan pengetahuan baru dan mengasah keterampilan (Chu \& Chen, 2016).

\section{PENUTUP}

Pada penelitian ini, kami telah mengembangkan desain pembelajaran jarak jauh berbasis e-learning pada pembelajaran fisika yang valid dan praktis melalui model pengembangan ADDIE. Beberapa penemuan dari studi yang dilakukan mengindikasi bahwa e-learning memberikan pengalaman positif bagi peserta didik dari segi kualitas konten, materi, dan tampilan media yang diberikan. Hasil dari penelitian yang dilakukan juga memberikan informasi lanjutan mengenai pentingnya media dalam pembelajaran fisika untuk meminimalisir miskonsepsi dan salah persepsi. Hal ini karena media yang dikembangkan bersifat multirepresentatif yang membantu peserta didik memahami materi secara mendalam.

Akan tetapi, di sisi lain, karena ukuran sampel yang digunakan kecil, tingkat efektivitas produk belum dapat ditentukan. Oleh karena itu, penelitian lanjutan yang melibatkan ukuran sampel dalam jumlah besar diperlukan untuk mengetahui kualitas desain produk yang 
dikembangkan secara detail.

\section{UCAPAN TERIMAKASIH}

Terima kasih kepada Dr. Ida Sriyanti, S. $\mathrm{Pd}, \mathrm{M}$. Si dan Dr. Leni Marlina, S. Pd, M. Pd dari Universitas Sriwijaya yang telah membantu dalam proses validasi produk penelitian. Kami juga mengucapkan terima kasih kepada SMA Negeri 15 Palembang yang telah berpartisipasi dalam penelitian ini.

\section{REFERENSI}

Al-Arimi, A. M. A. K. (2014). Distance learning. Procedia-Social and Behavioral Sciences, 152, 82-88.

Al-Mutawa, A. (2017). Higher Education in the Digital Age, Higher Education in the Gulf States: Present \& Future. Springer: Berlin, Germany.

Alshammari, M., Anane, R., \& Hendley, R. J. (2015). Design and usability evaluation of adaptive e-learning systems based on -a knowledge and learning style. In IFIP Conference on Human-Computer Interaction (pp. 584-591).Springer, Cham.

Bakri, F., Muliyati, D., \& Nurazizah, I. (2018). Website e-learning berbasis modul: bahan pembelajaran fisika sma dengan pendekatan discovery learning. WaPFi (Wahana Pendidikan Fisika), 3(1), 90-95.

Branch, R. (2009). Instructional Design. In Understanding Medical Education. Springer Science+Business Media. https://doi.org/10.1007/978-0-387-095066.

Brown, M., Hughes, H., Keppell, M., Hard, N., \& Smith, L. (2015). Stories from students in their first semester of distance learning. International Review of Research in Open and Distributed Learning, 16(4), 1-17.

Bušelić, M. (2012). Distance Learningconcepts and contributions. Oeconomica Jadertina, 2(1), 23-34.

Cavus, N. (2015). Distance Learning and Learning Management Systems. Procedia - Social and Behavioral Sciences, 191, 872-77. https://doi.org/1 0.1016/j.sbspro.2015.04.611

Chen, R., Ding, X., \& Min, W. (2021). The Contributions of Education to the Green GDP. In Educational Research in China (pp. 261-276). Springer, Singapore.

Chu, T. H., \& Chen, Y. Y. (2016). With good we become good: Understanding e-learning adoption by theory of planned behavior and group influences.Computers \& Education, 92, 37-52.

Dobre, I. (2012). An Overview of the Most Important Aspects Related to Quality Assurance in Computer Supported Collaborative E-Learning. International Journal of Computer Science Research and Application, 2(1), 25-30.

Domun, M. \& Bahadur, G. (2014). Design and development of a self-assessment tool and investigating its effectiveness for elearning. European Journal of Open, Distance and e-Learning, 17(1). Retrieved from http://www .eurodl. org/ materials/contrib/2014/Domun_Bahadur. pdf Kim, M.K., Kim, S.

Durrani, N., Halai, A., Kadiwal, L., Rajput, S. K., Novelli, M., \& Sayed, Y. (2017). Education and social cohesion in Pakistan. Project Report. UNICEF.

Guragain, N. (2016). E-learning benefits and applications.

Hirata, Y. (2018). E-learning courseware for language education in Japan: Its application and student perceptions. Open Learning: The Journal of Open, Distance and e-Learning, 33(2), 83-98.

Huda, S., Rinaldi, A., Suherman, S., Sugiharta, I., Astuti, D. W., Fatimah, O., \& Prasetiyo, A. E. (2019). Understanding of mathematical concepts in the linear equation with two variables: Impact of elearning and blended learning using google classroom. Al-Jabar: Jurnal Pendidikan Matematika, 10(2), 261-270.

Iftakhar, S. (2016). Google classroom: what works and how. Journal of Education and Social Sciences, 3(1), 12-18.

Irianti, N. P., \& Wijaya, E. M. S. (2017). Pengembanagn Media Pembelajaran ELearning Berbasis Moodle Pada Pokok Bahasan Lingkaran Kelas VIII SMP. JIPM 
(Jurnal Ilmiah Pendidikan Matematika), 5(2), 122. https://doi.org/ 10.25273/ji pm.v5i2.1175.

Kovbasnyuk, N., \& Styfanyshyn, I. (2020). Distance learning. Матеріали конфе рениій Молодіжної наукової ліги, 38-39.

Kulkarni, P. V., Rai, S., \& Kale, R. (2020). Recommender system in elearning: a survey. In Proceeding of International Conference on Computational Science and Applications (pp. 119-126). Springer, Singapore.

Irianti, N. P., \& Wijaya, E. M. S. (2017). Pengembanagn Media Pembelajaran ELearning Berbasis Moodle Pada Pokok Bahasan Lingkaran Kelas VIII SMP. JIPM (Jurnal IImiah Pendidikan Matematika), 5(2), 122-130.

Lecon, C., \& Hermann, M. (2020). Learning for E-Learning. In 7th International Conference on Computer Science, Engineering and Information Technology (CSEIT 2020) (pp. 26-27).

Lee, J. (2014). An exploratory study of effective online learning: Assessing satisfaction levels of graduate students of mathematics education associated with human and design factors of an online course. International Review of Research in Open and Distributed Learning, 15(1), 111-132.

Lister, M. (2014). Trends in the design of elearning and online learning. Journal of Online Learning and Teaching, 10(4), 671.

Markova, T., Glazkova, I., \& Zaborova, E. (2017). Quality issues of online distance learning. Procedia-Social and Behavioral Sciences, 237, 685-691.

Maryam, E. M. E. (2021). Penggunaan Layanan Aplikasi Google Classroom Untuk Meningkatkan Hasil Belajar Fisika Mahamahasiswa Universitas Bina Insan. Journal of Education and Culture, 1(1).

Misut, M., \& Pribilova, K. (2015). Measuring of Quality in the Context of e-Learning. Procedia-Social and Behavioral Sciences, 177, 312-319.

Ngalim, P. (2010). Prinsip-Prinsip dan Teknik Evaluasi Pengajaran. Remaja Rosdak arya.

Nyandra, M., Kartiko, B. H., Susanto, P. C., Supriyati, A., \& Suryasa, W. (2018). Education and training improve quality of life and decrease depression score in elderly population. Education and training improve quality of life and decrease depression score in elderly population. Eurasian Journal of Analytical Chemistry, 13(2).

Popa, E. M., \& Stănculea, L. (2012). What is good e-learning. Journal of Knowledge Management, Economics and Information Technology, 2(4), 30-37.

Rakhman, A., \& Alam, S. K. (2020). Implementasi Pembelajaran Jarak Jauh Dalam Meningkatkan Life Skill Pada Anak Usia Dini. Tunas Siliwangi: Jurnal Program Studi Pendidikan Guru PAUD STKIP Siliwangi Bandung, 6(2), 9-17.

Reynolds, K., Becker, K., \& Fleming, J. (2014). Contemporary Challenges in E-learning. In Workforce Development (pp. 269-282). Springer, Singapore.

Salehudin, M. (2020). Dampak Covid-19: Guru Mengadopsi Media Sosial Sebagai ELearning Pada Pembelajaran Jarak Jauh. Jurnal MUDARRISUNA: Media Kajian Pendidikan Agama Islam, 10(1), 1-14.

Songbin, B., \& Fanqi, M. (2015). The design of massive open online course platform for English translation learning based on Moodle. In 2015 Fifth International Conference on Communication Systems and Network Technologies (pp. 13651368). IEEE.

Swan, K., Day, S., Bogle, L., and Matthews, D. (2014). A collaborative, design-based approach to improving an online program. The Internet and Higher Education, 21, 74-81.http://dx.doi .org/10.1016/j.ih educ .2013 .10 .006 .

Teräs, H., \& Herrington, J. (2014). Neither the frying pan nor the fire: In search of a balanced authentic e-learning design through an educational design research process. The International Review of Research In Open And Distance Learning, 15(2). Retrieved from http://www.irrodl.org/index.

Traxler, J. (2018). Distance learning- 
Predictions and possibilities. Education Sciences, 8(1), 35.

TRU, N. A. (2019). The Relationship between Education, Economic Growth and Unemployment: Evidence in Eastern Europe. European Journal of Educational and Social Sciences, 4(1), 55-72.

Uppal, M. A., Ali, S., \& Gulliver, S. R. (2018). Factors determining e-learning service quality. British Journal of Educational Technology, 49(3), 412-426.

Wiyono, K., Zulherman, Z., Saparini, S., Ariska, M., Khoirunnisa, R., \& Zakiyah, S. (2020). Moodle-based E-Learning Model for Critical Thinking in the Lesson of Electromagnetic Induction. Jurnal Penelitian \& Pengembangan Pendidikan Fisika, 6(2), 237-246.

Zamani, A. Z., \& Nurcahyo, H. (2016). Pengembangan media pembelajaran berbantuan komputer untuk meningkatkan motivasi dan hasil belajar. Jurnal Pendidikan Matematika dan Sains, 4(1), 89-100. 